PUPIL: International Journal of Teaching, Education and Learning

ISSN 2457-0648

Maria Sharron De Asis-Ricamora, 2022

Volume 5 Issue 3, pp. 183-202

Received: 17 th May 2021

Revised: 11 th August 2021, 07 th December 2021, 30 th December 2021

Accepted: $5^{\text {th }}$ January 2022

Date of Publication: 05 th February 2022

DOI- https://doi.org/10.20319/pijtel.2022.53.183202

This paper can be cited as: De Asis-Ricamora, M. S. (2022). The Covidization of English Language Teaching: Concepts, Experiences, Insights, and Reflections of ESL Teachers. PUPIL: International Journal of Teaching, Education and Learning, 5(3), 183-202.

This work is licensed under the CreativeCommons Attribution-NonCommercial 4.0 International License. To view a copy of this license, visit http://creativecommons.org/licenses/by-nc/4.0/ or send a letter to Creative Commons, PO Box 1866, Mountain View, CA 94042, USA.

\title{
THE COVIDIZATION OF ENGLISH LANGUAGE TEACHING: CONCEPTS, EXPERIENCES, INSIGHTS, AND REFLECTIONS OF ESL TEACHERS
}

\author{
Maria Sharron De Asis-Ricamora, M.A. \\ Graduate School, Emilio Aguinaldo College, Manila, Philippines \\ sharonn.ricamora@eac.edu.ph
}

\begin{abstract}
This phenomenological research describes the concepts, experiences, insights, and reflections of ESL teachers on the covidization of language teaching amid the COVID-19 outbreak. A total of 19 informants from both public and private institutions agreed to participate in this research. Results of the study show that concepts on covidization centralized on utilization of different teaching modalities, challenges, pedagogical changes, and effects of the pandemic in language education. Experiences were expressed as positive and negative encounters in teaching. Moreover, their insights lead to suggestions to utilize appropriate strategies and methodologies in teaching English, exposure to ICT training, capacity-building, management support, and emotional support Covidization the outbreak and visualized their deep desires to move forward and accept the challenges with a positive goal in mind.
\end{abstract}

Keywords

Covidization, Concepts, Experiences, Insights, Reflections, ESL Teachers 


\section{Introduction}

Madhukar Pai from the University of Montreal coined the term 'covidization' to express his thoughts on the alarming and worrisome effects of the pandemic in the fields of science research funding, production, and publication (Adam, 2020). Covidization does not exist in the sectors mentioned by Madhukar Pai. Undoubtedly, they represent just a fraction of the sectors that are affected by this occurrence. It has equally disrupted education, most especially learners who belong to the vulnerable sectors of society. Data from the United Nations (2020) report anticipates 23.8 million learners across all levels are expected to be out of school in the current year.

In the Philippines, the start of the covidization in the educational sector started on March 10, 2020, as the government responded to avoid the spread of the virus (Tomacruz, 2020). It prompted the closures and suspension of operations of 748 private institutions due to difficulties in keeping their schools afloat and unpreparedness to implement online modalities in teaching (CNN Philippines, 2020). On the other hand, the Department of Education resorted to the production, printing, delivery, and retrieval of free self-learning modules to all public-school students across all levels and in all regions of the country to ensure the deliverance of learning amidst the present condition (DepEd, 2020). Moreover, private schools remain steadfast by utilizing existing online and software-based Learning Management Systems (LMS) to facilitate and deliver synchronous and asynchronous classes. However, despite all the remedies the academic community has devised to remediate this situation, the difficulty to facilitate learning remains unresolved. Issues on social integration, peer culture, and the unnaturalness of online learning were the primary concerns (Joaquin et al., 2020). In the words of Joe Heim (2020) from the Washington Post, "the coronavirus pandemic has rewritten the syllabus for the 2020-2021 school year as teachers are faced with formidable challenges, whether educating students in masked-up, socially distant classrooms or virtually, from computer screens."

For language learning, the opportunity is put to a halt due to the pandemic (Buchanan, 2020). Teachers of foreign languages were forced to reposition themselves to an unfamiliar teaching environment, which resulted in redesigning lessons, adapting materials, and looking for engaging methods to ensure efficient delivery of lessons and create a more positive teaching and learning environment (Maican \& Cocorada, 2021). The covidization of language classrooms limits the avenue for social interaction. Verga and Kotz (2013) emphasized the complexity of human 
language and the role of human interaction in language learning is more than the coding and decoding of linguistic utterances. Vygotsky (1978) as cited by Mahn (2013) emphasized the need for interaction as he views learning as a social activity. While we understand that we are now facing a very challenging time and that the modality of learning has transitioned into something unconventional, it has to be emphasized that purely online provision is generally perceived to be less effective than face-to-face components (Miliszewska, 2007).

Challenges in the drastic change of modality from traditional face-to-face to remote, online, or blending distance learning resulted in the reconfiguration of classroom instruction from 2020 to the present. Digital technology is identified as the driving force of language education during this unprecedented moment in our lives. However, technical and system readiness seemed to be the primary impediment to ensuring success in learning. To date, many countries are still in the process of reinventing their policies and curriculum to make them more suitable and adequate for online learning. English language teachers are adamant about the change of modality. Hence, digital technology is identified to be an obstruction in the language process. It has isolated language learners to be exposed to real-world interactions. An obvious disparity in the enhancement of language skills was identified. For some, online modality in language learning is negated because it limits real interaction or the real use of the language (Archila, 2014). On the contrary, several studies also show that online language learning is at par or sometimes slightly superior to face-toface courses (Blake, Wilson, Cetto \& Pardo-Ballester, 2008; Chenoweth \& Murday, 2003; Despain, 2003; Isenberg, 2010 as cited by Montiel-Chamorro, 2018).

The key interest of this research is to describe the language teaching concepts, experiences, insights, and reflections of English language teachers amidst the covidization of teaching in the Philippines. This research intends to exemplify teachers and highlight the aspects of context, content, communications, design, delivery, virtual classroom, management, interaction, and online learning community (Sun, 2011; Barrett, 2008) in teaching English. The changing paradigm of English language teaching using digital technology and other modalities will likewise immerse through the insights and reflections of the informants. In addition, it is also critical to investigate the insights and reflections of English teachers on how they are navigating language teaching using various modalities. 


\section{Literature Review}

This part of the paper reviews studies, theories, and concepts related to the covidization of English language teaching. Thus, it intends to give a clearer perspective on challenges encountered by teachers and the changing modalities brought by the global health crisis. The researcher then curated the most relevant topics to put the readers in the proper context.

\subsection{COVID-19 and the Changing Modalities of Teaching}

COVID-19 has changed the dynamics of learning from face-to-face to blended learning, modular or online learning. In English Language Teaching, the typical face-to-face discussions, formal and informal discourse, were replaced by student inquiries and teachers providing clarifications (Fatima, 2020). The initial phase of transition was the toughest as queries on internet connectivity, content delivery, student attendance, teacher training on digitalization, communication via social media channels, and efficient activities were raised and needed to be resolved (Ribeiro, 2020; Gao and Zhang, 2020). In other words, teachers had to reconfigure classes for an emergency remote teaching or distance education in the (Hodges, Moore, Lockee, Trust, \& Bond (2020) as cited by Yi and Jang (2020); Karatas \& Tuncer, (2020). Teachers' cognition on education and language teaching dramatically changed. In the research conducted by Gao and Zhang (2020) and Watkins (2020), teachers felt worried, anxious, stressed, and burnout due to their unfamiliarity with the teaching modality given the short amount of time allotted for preparation and training. Pedagogical adaptation from traditional face-to-face to remote learning and the recalibration of instructional management to teach, engage, do administrative tasks are some of the crucial factors to be considered during the pandemic (Barron et al., 2021).

The year 2020 was called the most extensive education disruption in history due to COVID with 148,424,599 affected learners and 33 country-wide closures based on March 31, 2021 data (UNESCO, 2020). As a result, digital technology is perceived as one of the critical factors in delivering lessons throughout the pandemic. Loose \& Ryan (2020) emphasized the increasing popularity of online learning. Educational institutions worldwide resorted to digital platforms' adoption with an $\$ 18.66$ billion- $\$ 350$ billion projected market by 2025 for language applications, virtual tutoring, video conferencing, and online learning software investment (Li \& Lalani, 2020). There was a smooth transition from face-to-face to online environments in Finland, as teachers were trained to use educational technology five years before the lockdown (Iivari \& VentsOlkonen, 2020). In the case of Scotland, educational technology transitioned into cloud-based 
service, which includes an authentication portal, Microsoft Office 365, Google G-Suite for Education, and WordPress Blogs (European Commission, 2021). ESP students in Russia showed a positive attitude towards language learning through virtual platforms considering that there are problems encountered with their internet connection (Waicekawsky et al., 2020).

For basic education in the Philippines, the Department of Education addressed these difficulties by putting together a policy called Basic Education Learning Continuity Plan (BELCP) under DepEd Order No. 012, series of 2020, per Section 1, Article XIV of the 1987 Constitution on educational equality and accessibility of education to all. The policy simply states state schools may use any modalities depending on their localities' present state, accessibility of tools, and circumstances of the learners with the locality. Face-to-face, distance learning, blended learning, and homeschooling are the varying modalities in learning delivery. Delivery and distribution of modules, mass production of learning materials, financial resources, holistic development of students, quality of learning were some of the department's hurdles. (PimentelTibon, 2020)

The Commission on Higher Education reported that several Higher Educational institutions resorted to distance learning, blended learning, online learning, and other modalities to support learning delivery. The adaptation of Learning Management Systems (LMS) and videoconferencing applications and utilization of social media and YouTube videos were encouraged to reinforce classroom instruction. (CHED, 2020)

\subsection{Challenges in Language Teaching Amidst the Pandemic}

There are several impediments to ensuring remote and online learning effectiveness, such as teachers' readiness, availability and accessibility of technology, and learners' support (ACER Discover, 2020). Technological support, infrastructure availability, faculty and students (Kumar \& Gautam, 2021; Oyedotun, 2020; Uro et al., 2020), emotional uncertainty, lack of peer interaction, at-risk youth, teacher proficiency in technology, the integrity of assessment and output (Cardullo, 2021) were further identified as major obstructions during the pandemic. Among language teachers, disparities in access to and use of technology, biases that are baked into many software programs and digital platforms, and language learners' need for authentic social interaction are major problems that need to be resolved amid online learning. To understand the need for authentic interaction, teachers are encouraged to select suitable technologies that match the lesson's purpose, frequent opportunities for interaction with peers and teachers via video chats 
to group texts, e-mails, virtual classroom discussion, and use of software for self-paced learning are recommended. (Altavilla, 2020).

Harrison (2020) presented three (3) reasons why technology brings language teachers to an alarming state. First, technology is isolating. This means that learner interaction can be limited and can be entirely different when language is used in the real world. Second, teachers are being deskilled with technology. Language teachers perceive that the true meaning of teaching falters. Third, with the existence of Artificial Intelligence (AI), the fear of losing their jobs and becoming dispensable is their concern. Djajadikerta et al. (2021) emphasized the need to prepare and support a web-based learning environment, the technology infrastructure, and the digital and mental capacities of academics and students.

Virtual teaching is perceived to be effective in changing the attitude of the students, exciting, convenient, and accessible as compared to traditional face-to-face teaching. On the contrary, lack of facilities, internet connectivity, lack of orientation, and expertise in technology use were some of the concerns raised by the students and teachers. Government support and funding, provision of the internet, training on virtual teaching for active learning, e-learning trends are to be considered to mitigate the problems. (Shahzad et al., 2020)

EFL teachers in China claim that they cannot go back in time and restart themselves when it comes to enhancing their knowledge and skills on technological skills and literacy (Gao \& Zhang, 2020). Moreover, Karatas \& Tuncer (2020) contends that the four language skills (reading, writing, listening, and speaking) are the heart of a language (L2) class. They added that language education before COVID-19 was about giving tasks or activities and integrating said skills. Their study shows that with suitable content, proper implementation of courses, and integration of language skills via distance education platforms, students will sufficiently benefit from it.

Another concern raised by teachers is that "many of the specific strategies teachers use with English learners don't translate easily into an online environment. For example, kids need to be speaking English, and teachers need to provide scaffolds to support them during academic discussions. That can be very challenging to do in a large, online classroom environment." (Parker, 2020)

TESOL practitioners in the United States expressed their concerns on student well-being, family, social and mental health, transition to online classes, employment and finances, physical health, and school work during the onset of the pandemic. Data shows that they experienced stress, 
and some teachers expressed frustration with online resources. Online approaches to language learning are perceived to impede the development of language skills. Although their writing skills improved, their listening, speaking, and grammatical skills were compromised based on the students' comments. Thus, there was an apparent disparity in the development of skills. The implication of this study highlights the importance of providing training to teachers on the use of technology for them to design suitable exercises, activities, and assignments to facilitate language development. The level of proficiency should be a distinguishing mark to provide appropriate methods. Students with low proficiency are recommended to have regulated face-to-face instruction, while students with higher proficiency levels may be given off-campus instruction. (Hartshorn \& McMurry, 2020)

\section{Statement of Purpose}

The purpose of this phenomenological study is to describe the covidization of English language teaching in the Philippines. The researcher intends to explore the concepts, experiences, insights, and reflections of the teacher-informants during the pandemic. Covidization is generally defined as the alarming effects of COVID-19 in English Language Teaching. This term was culled from the Madhukar Pai from the University of Montreal coined the term 'covidization' to express his thoughts on the alarming and worrisome effects of the pandemic in the fields of science research funding, production, and publication (Adam, 2020).

\section{Methodology}

This research utilized a phenomenological approach to explore the insights, experiences, and reflections of ESL teachers in the covidization of teaching. This approach is effective in elucidating data on a much deeper level. Creswell (2013) defines this type of study as a "description of the common meaning for several individuals of their lived experiences of a concept or a phenomenon."

A total of 19 teacher-informants from public and private schools in Manila, Philippines were purposefully chosen to be interviewed via online means to explore their concepts, experiences, insights, and reflections on the covidization of English Language Teaching. Broad and open-ended questions were asked during the online interview and were geared towards a common understanding of the informants' English Language Teaching experiences during the 
pandemic (Moustakas 1994 as cited by Creswell 2013). Data was then transcribed, cleaned, exported, coded, and sub-coded into nodes, segmented, and tabulated using a qualitative data analysis tool. From these processes, significant statements, meanings, themes, and extensive descriptions were generated as major results of the study. (Moustakas 1994 as cited by Creswell, 2013 )

\section{Results and Discussion}

The data was culled from 19 teacher-informants who are currently teaching across all levels in public and private schools in Manila, Philippines. After a thorough analysis of the responses, four (4) themes were immersed, namely: Covidization: A New Normal Parlance; Covidization: A Serious Ordeal; When I See Things Come into Place; Looking Back and Moving Forward. Tables were used to aid and sustain the readers' interest in understanding the cases.

\section{Theme 1: Covidization: A New Normal Parlance}

The word "covidization" is viewed as a new word by 3 or $16 \%$ of the participants. In general, covidization is defined as the restructuring of the teaching paradigm and the application and adaption of online modalities in English language teaching due to the COVID-19 pandemic. An informant clearly stated that "it is the new normal that may change the perspective/mindset of an English language teacher." (Michelle)

Covidization in the perspective of language teaching is defined as:

Table 1: Covidization in Relation English Language Teaching

\begin{tabular}{|l|l|}
\hline Code & Significant Statements \\
\hline Application to ELT & $\begin{array}{l}\text { "The covidization of the English language in the classroom } \\
\text { perhaps is the influence of the pandemic to the practice of the } \\
\text { English language in the online classroom setup." (Ambo) } \\
\text { "Covidization of English language classroom is a mere } \\
\text { understanding of a health crisis which should be applied in } \\
\text { every English teaching-learning practice." (Danny) } \\
\text { "It may relate to the relationship between the COVID debacle } \\
\text { and the language teaching pedagogy." (Betty) } \\
\text { "... a positive assurance that this transition in education shall } \\
\text { be embraced with utmost care and diligence." (Danny) }\end{array}$ \\
\hline
\end{tabular}




\section{Theme 2: Covidization: A Serious Ordeal}

"Difficult, hard, and challenging" (19 or 100\%) are the most noticeable words used by the informants when implored to relate their language teaching experiences in the pandemic. The researcher surmised that these difficulties focused on online and modular distance learning, online technology, delivery of lessons, utilization of interactive activities, language processes, assessment of language skills, student participation during virtual classes, and the self-learning method employed by public schools. While some expressed their recounts in more subtle narratives, 5 or $26 \%$ did not hesitate to express outright negation on their respective teaching modalities by uttering: "There has been no face to face interaction, and so learning is not that authentic"; "Face to face instruction should not be replaced by virtual learning. " Sun (2011) confirms this statement by mentioning that there is no replacement for the traditional classroom. No matter what the activities are in an online mode, students simply do not regard it as a "classroom."

Data shows that teachers suffer from stress, while others express frustration with online resources and infrastructure support from the school. Gao and Zhang (2020) claimed that teachers' cognition on education and language teaching dramatically changed. It is then natural for teachers to feel worried and anxious due to their unfamiliarity with the teaching modality given the short amount of time allotted for preparation and training. Thus, building teachers' confidence through ICT knowledge and technology capacity-building is crucial in rolling out a successful online class (Könij, Jäger-Biel \& Glutsch, 2020).

For the most part, it has been recognized that some students lack the motivation to learn during online classes. In most instances, teachers revealed that they refused to listen to instructions when given in English, refrained from participating in discussions, or disregarded turning over modules on time. The arduous implementation of modular distance learning cascaded to other issues like ensuring the integrity of answers submitted, dealing with parents who neglected to retrieve the modules of their children, monitoring activities, and contacting and communicating with students with no internet access.

Teachers were further confronted with more pressing issues concerning the language development of the students. It was indicative of their answers that strategies were relatively "controlled, limited and inauthentic in an online or distance modular learning". One participant also commented on the inefficacy of group activities in an online mode. Alvila (2020) suggests that for authentic interaction to manifest, teachers are encouraged to select suitable technologies 
that match the purpose of the lesson. Frequent opportunities for interaction with peers and teachers via video chats to group texts, e-mails, virtual classroom discussion, and software for self-paced learning are also added by Altavilla (2020). Moreover, it was pointed out by one of the interviewees that "the time allotment for synchronous classes imposed by their specific schools affected the language learning process, which is identified to be highly necessary for language development." The interview also revealed that the development of macro-skills was constricted to reading and writing skills due to this issue. Most of the answers suggested that oral skills were compromised due to poor internet connectivity, technical difficulties, and noise or distortions created in the background during online classes. These are considered barriers in the assimilation of language and are instrumental to the learner's lack of focus and participation. In other words, it is difficult to ensure the effective delivery of the key competencies indicated in the English language curriculum. In the study of Parker (2020), teachers raised that "many of the specific strategies teachers use with English learners don't translate easily into an online environment. For example, kids need to be speaking English, and teachers need to provide scaffolds to support them during academic discussions. That can be very challenging to do in a large, online classroom environment." For some teachers, online modality in language learning is negated because it limits real interaction or the real use of the language (Archila, 2014). In a language classroom, students are expected to be more collaborative and expected to be active listeners during peer or group activities, role play, and games (Yousaf et al., 2017; Ndhlovu, 2017; Abrejo et al., 2019). On the other hand, teachers are mere facilitators and monitors in the classroom. Language curriculum is redesigned to be more skills-based, functional, and purpose for specific settings or disciples. Information-gap, jigsaw, task-completion, opinion-sharing, information-transfer, reasoning-gap, role-plays are suggested activities for communicative language teaching (Richards, 2006). Language teaching connotes the strengthening of the macro skills: Listening, Speaking, Reading, and Writing. As Saduki (2015) mentioned, these four (4) give learners "scaffolded support, opportunities to create, contexts in which to use the language for exchanges of real information, evidence of their ability (proof of learning) and, most importantly, confidence."

While some informants felt restrained by certain circumstances and policies in their schools, others benefited from what technology offers. In several accounts, it was used as the primary tool to deliver lessons and communicate with the students and parents. The use of phones and social media platforms paved the way for facilitative interactions and collaborative 
engagements with students. This was suggestive of their responses when prompted to talk about their experiences in conducting online classes as shown in the table below.

Table 2: Some Positive Experiences

\begin{tabular}{|l|l|}
\hline Code & Significant Statements \\
\hline Positive Experiences & $\begin{array}{l}\text { We only need to think of how many of us now use our phones } \\
\text { and social media such as WhatsApp or Facebook to } \\
\text { communicate. }\end{array}$ \\
\hline & $\begin{array}{l}\text { We still have collaborative conversations strategies during } \\
\text { the pandemic however the modality is digital. }\end{array}$ \\
\hline $\begin{array}{l}\text { As a private school teacher in the English subject, the } \\
\text { majority of the students have the advantage of nurturing the } \\
\text { language in and out of the virtual classrooms. }\end{array}$ \\
\hline
\end{tabular}

In essence, the pandemic is used as an opportunity to learn new platforms, re-learn concepts, and sustain and strengthen language skills, teaching, personal and professional skills. Shahzad et al. (2020) proved that virtual education is perceived as effective in changing students' attitudes by making it more exciting, convenient, and accessible. Moreover, Karatas \& Tuncer (2020) contends that the four language skills (reading, writing, listening, and speaking) are the heart of a language (L2) class. They added that language education before COVID-19 was about giving tasks or activities and integrating said skills. With this, it must be highlighted that with suitable content, proper implementation of courses, and integration of language skills via distance education platforms, students will sufficiently benefit from it.

\section{Theme 3: When I See Things Come into Place}

The covidization of language learning introduced new opportunities and meaningful insights for language teachers. The basic foundation of participants' understanding is grounded on the Commission on Higher Education (CHED) Language Learning guidelines, Department of Education (DepEd) Most Essential Learning Competencies, institutional curriculum standards, syllabus, and prominent language theories. For the teacher-informants, the policies and existing language theories set a complete guide in crafting appropriate English language lessons, materials modules, and activities regardless of the current situation brought by the pandemic.

Teachers were compelled to employ a variety of ways to help students cope with the current modality. It is evident that the long haul in education in times of pandemic recreated and restructured the traditional teaching paradigm by fusing methods that they perceived to be 
sufficient given the situation. It is also reflected in their testimonies that they have established their respective schemes in teaching. Given their experience, they were emphatic on developing new designs suitable for different modalities, hiring a team of experts for ICT training, capacitybuilding and professional development, and creating guidelines in the institution. The informants, therefore, purport some approaches as indicated in their responses in the table below.

Table 3: Insights: How the English Language is Taught

\begin{tabular}{|c|c|}
\hline Code & Significant Statements \\
\hline \multirow[t]{6}{*}{ Insights } & $\begin{array}{l}\text { "In classroom teaching now, much time is spent for teacher's } \\
\text { explanation on PowerPoint presentations leaving students to } \\
\text { listen to their teachers carefully. Interactions may come in } \\
\text { through chat box if students refuse to recite." (Danny) }\end{array}$ \\
\hline & $\begin{array}{l}\text { "Writing (texting) became the new mode of communication } \\
\text { replacing the speaking skill." (Pearl) }\end{array}$ \\
\hline & $\begin{array}{l}\text { "We can ask the students to participate online via recitation and } \\
\text { encourage them to speak even if it is grammatically incorrect. } \\
\text { The point here is, we can help the students to practice speaking } \\
\text { in English and, at the same time, to boost their confidence } \\
\text { without humiliating them. It might be a hassle on our part, but } \\
\text { we can jot down the answers of the students [via online } \\
\text { recitation] and correct their grammar privately [via online } \\
\text { chat] so that they will not feel humiliated." (Che) }\end{array}$ \\
\hline & $\begin{array}{l}\text { "Encourage peer instruction thru breakout sessions or } \\
\text { empower parents/guardian to help in the language instruction." } \\
\text { (Betty) }\end{array}$ \\
\hline & $\begin{array}{l}\text { "As teachers prepare lessons, they often incorporate new } \\
\text { strategies-graphic organizers, mnemonics, charts, word } \\
\text { banks, written outlines, and other materials-in the hope } \\
\text { that variety will attract and hold student interest." (RP) }\end{array}$ \\
\hline & $\begin{array}{l}\text { "I select lessons that accommodate multiple key competencies." } \\
\text { (Sarah) }\end{array}$ \\
\hline
\end{tabular}


With the current setup, one informant emphasized that: "to ensure success in language learning: motivation, resilience, communication skills, adaptive skills, linguistics competence, and reading comprehension (Michelle). In like manner, educational institutions worldwide resorted to digital platforms' adoption with an $\$ 18.66$ billion-\$350 billion projected market by 2025 for language applications, virtual tutoring, video conferencing, and online learning software investment (Li \& Lalani, 2020). For example, there was a smooth transition from face-to-face to online environments in Finland as teachers were trained to use educational technology five years before the lockdown (Iivari \& Vents-Olkonen, 2020). In Scotland, educational technology transitioned into cloud-based services, including authentication portal, Microsoft Office 365, Google G-Suite for Education, and WordPress Blogs (European Commission, 2021).

\section{Theme 4: Looking Back and Moving Forward}

The final question posed to the informants was, "What could you have done differently". This question intends to elucidate a sense of reflection on the conventional pedagogies and concretize new plans for their succeeding ventures as English language teachers. Most importantly, in forging ahead, it is important to identify the infrastructure requirements, teaching tools, skills, development plans and policies, and pertinent curricular revisions. This final question necessitated them to make sense out of their experiences and learnings from the onset of the Covid-19 pandemic.

Danny revealed that "the situation was unexpected". In retrospection, enhancement of technical skills and technological advancements, reinforcement of professional development programs (module-making, facilitation speaking in synchronous class and writing with integrity), implementation policies and guidelines for the integration of ICT, development of online instruction materials) should have been done in preparation for an outbreak. EFL teachers in China claim that they cannot go back in time and restart themselves when it comes to enhancing their knowledge and skills on technological skills and literacy (Gao \& Zhang, 2020). Moreover, curriculum support is identified to promote meaningful learning experiences in online learning by incorporating various seminars and a series of training, partnerships, and projects at a national level were accomplished (European Commission, 2021).

One interviewee mentioned the importance of language in the educational spectrum. He emphasized that language teaching still has to take place and be successful whatever the situation may be. In terms of technical skills, Annaliza raised that "one must understand the need to equip 
himself with the desirable ICT skills for online teaching." Furthermore, in the covidization of language teaching, the emphasis has to be on creativity, new strategies, implementing guidelines, capacity-building, and preparation of materials anchored to facilitate the emergency needs of the learners. It must therefore be a "phenomenal adaptation of language context" (Nhor). Teachers' cognition on education and language teaching dramatically changed. In research conducted by Gao and Zhang (2020), teachers felt worried and anxious due to their unfamiliarity with the teaching modality given the short amount of time allotted for preparation and training. Pedagogical adaptation from traditional face-to-face to remote learning and the recalibration of instructional management to teach, engage, do administrative tasks are some of the crucial factors to be considered during the pandemic (Barron et al., 2021).

Beyond the curriculum, the learning paradigm in the new normal posits independent learning among students. Above all, teachers must establish a "trustful relationship between the teachers and students" (Betty). Language teaching at the time of pandemic means "to guide and nurture a child, to treasure knowledge, skills, abilities, and wisdom, to challenge every opportunity that society may face, and to be an active agent in transforming the world." Amidst all the hurdles, a teacher must effect change by infusing a learning environment that is focused and well-prepared, sensitive, encouraging, and supportive by making their students feel that language learning is not an ordeal that they have to overcome. TESOL practitioners in the United States similarly emphasized their concerns on student wellbeing, family, social and mental health, transition to online classes, employment and finances, physical health, and school work during the onset of the pandemic. (Hartshorn \& McMurry, 2020)

\section{Conclusion}

The Covid-19 pandemic caused pedagogical changes in the teaching of the English language in the Philippines. Admittedly, it is difficult, challenging, and arduous to navigate the current situation. Eventually, teachers coped by resorting to various modalities, tools, strategies, and methods to aid and facilitate language learning. Deficiency in online skills and lack of technological support and preparation were identified to be the most challenging problems that surfaced during the data analysis. Thus, the need for government and institutional support in equipping teachers with efficient technical infrastructure, professional development programs, and related policies and guidelines is vital in ensuring the success of this endeavor. 
Additionally, student motivation and interest in learning were recognized to be another factor in the problem. Students show poor motivation by not responding when asked. It leads to the deteriorating quality of English language instruction. Evidence points out that students refrained from engaging in real interactions, which hampered the enhancement of listening and speaking skills. The type of teaching modality utilized by the teachers is attributed to the declining interest of the students. Given these circumstances, teachers are still expected to extend their tolerance by being more sensitive, creative, and sympathetic to students' needs amid a global crisis. Even so, it does not imply compromising the much-needed skills in the development of the language among students. Language teachers and educational leaders are now being challenged to be more proactive in the adaptation of new normal teaching pedagogy and effective and alternative modalities that could ultimately address the present needs of English language learners. Most importantly, considering that this study is confined within the experiences, reflections, and insights of the informants, there is an urgent need to investigate further by exploring and describing how English Language Teaching should transform. Therefore, future researchers are directed to look into its pedagogical implications in terms of teaching methods, remediating strategies, and key competencies to rise above this challenge. With this, guidelines, toolkits, and models can be developed as a basis to help English teachers, educational leaders, and government officials navigate the new normal setup.

\section{REFERENCE}

Abrejo B., Sartaj S, \& Memom S., English Language Teaching through Communicative Approach: A Qualitative Study of Public Sector Colleges of Hyderabad, Sindh. Advances in Language and Literary Studies, 10 (5). http://dx.doi.org/10.7575/aiac.alls.v.10n.5p.43

ACER Discover. (2020, October 5). Teaching over technology: educational priorities during COVID-19. ACER Discover. https://www.acer.org/gb/discover/article/teaching-overtechnology-educational-priorities-during-covid-19

Adam, D. (2020, December 17). Scientists fear that 'covidization' is distorting research. Springer Nature Limited, 588, 358-359. https://doi.org/10.1038/d41586-020-03388-w

Altavilla, J. (2020). How technology affects instruction for English learners. Sage Journals. https://doi.org/10.1177/0031721720956841 
Archila, Y. (2014). Interaction in a Blended Environment for English Language Learning. Gist Education and LEarninG rEsEarch Journal, 9. 142-156. https://files.eric.ed.gov/fulltext/EJ1062505.pdf

Barrett, K. (2008). An Exploration of EFL Teachers' and Learners' Lived Experiences in a Synchronous Online VOI-Enabled Cross-Cultural Language Learning Environment. Proquest LLC. https://media.proquest.com

Barron, M., Cobo, C., Munoz-Najar, A., \& Sanchez, I. (2021, February 18). The changing role of teachers and technologies amidst the COVID 19 pandemic: key findings from a crosscountry study. World Bank Blogs. https://blogs.worldbank.org/education/changing-roleteachers-and-technologies-amidst-covid-19-pandemic-key-findings-cross

Buchanan, Y. (2020, October 18). Language learning is being stifled in the pandemic. The Daily Iowan. https://dailyiowan.com/2020/10/18/opinion-language-learning-is-being-stifledin-the-pandemic/

Cardullo, V., Wang, C., Burton, M., \& Dong, J. (2021). K-12 teachers' remote teaching selfefficacy during the pandemic. Journal of Research in Innovative Teaching \& Learning, 14(1), 32-45. https://doi.org/10.1108/JRIT-10-2020-0055

Commission on Higher Education. (2020). Guidelines of the Implementation of Flexible Learning, https://ched.gov.ph/wp-content/uploads/CMO-No.-4-s.-2020-Guidelines-onthe-Implementation-of-Flexible-Learning.pdf

CNN Philippines. (2020, September 9). 748 private schools suspend operations this school year, DepEd says. CNN Philippines. https://www.cnnphilippines.com/news/2020/9/9/Private-schoolstemporary-closure-DepEd-.html

Creswell, J. (2013). Qualitative Inquiry and Research Design: Choosing Among Five Approaches (Third ed.). Sage Publications Inc.

DepED. (2016). K to 12 Curriculum Guide ENGLISH. https://www.deped.gov.ph/wpcontent/uploads/2019/01/English-CG.pdf

DepEd. (2020). DepEd prepares Self-Learning Modules for education's new normal. Republic of the Philippines-Department of Education. https://www.deped.gov.ph/2020/07/02/depedprepares-self-learning-modules-for-educations-new-normal/

Djajadikerta, H., Trireksani, T., Ong, T., Roni, S., Kazemian, S., Zhang, J., Noor, A., Ismail, S., Ahmad, M., Azhar, Z., Shahbu, A., Maradona, A., Yanto, H., \& Wahyuningrum, I. 
(n.d.). Australian, Malaysian and Indonesian Accounting Academics' Teaching Experiences During the COVID-19 Pandemic. AABFJ, 15(2).

https://doi.org/10.14453/aabfj.v15i2.7

European Commission. (2021, February 24). Supporting educational continuity through digital technology during the Covid-19 pandemic. Eurydice. https://eacea.ec.europa.eu/nationalpolicies/eurydice/content/supporting-educational-continuity-through-digital-technologyduring-covid-19-pandemic_en

Fatima, N. (2020). English Language Teaching During the Times of COVID-19- Challenges and Opportunities: A Brief Study of GFP Students in Muscat College. Journal for Research Scholars and Professionals of English Language Teaching, 4(21).

Gao, L., \& Zhang, L. (2020). Teacher Learning in Difficult Times: Examining Foreign Language Teachers' Cognitions About Online Teaching to Tide Over COVID-19. Frontiers in Psychology, 15. https://doi.org/10.3389/fpsyg.2020.549653

Harrison, G. (2020, April 5). English teaching and learning during the Covid crisis: online classes and upskilling teachers. Cambridge Assessment. https://www.cambridgeenglish.org/blog/english-teaching-and-learning-during-the-covid$\underline{\text { crisis/ }}$

Hartshorn, K., \& McMurry, B. (2020). The Effects of the COVID-19 Pandemic on ESL Learners and TESOL Practitioners in the United States. International Journal of TESOL Studies, 2(2). https://doi.org/10.46451/ijts.2020.09.11

Heim, J. (2020, October 6). Pandemic teaching, in their words. The Washington Post. https://www.washingtonpost.com/education/2020/10/06/teacher-pandemic-essays/

Iivari, N., \& Vents-Olkonen, L. (2020). Digital transformation of everyday life - How COVID19 pandemic transformed the basic education of the young generation and why information management research should care? International Journal of Information Management, 55. https://doi.org/10.1016/j.ijinfomgt.2020.102183

Joaquin, J., Biana, H., \& Dacela, M. (2020, October 22). The Philippine Higher Education Sector in the Time of COVID-1. Frontiers in Education. https://doi.org/10.3389/feduc.2020.576371 
Karatas, T., \& Tuncer, H. (2020). Sustaining Language Skills Development of Pre-Service EFL Teachers despite the COVID-19 Interruption: A Case of Emergency Distance Education. Sustainability 2020. https://doi.org/10.3390/su12198188

Könij, J., Jäger-Biela, D., \& Glutsch, N. (2020). Adapting to online teaching during COVID-19 school closure: teacher education and teacher competence effects among early career teachers in Germany. European Journal of Teacher Education, 43(4), 608-622. https://doi.org/10.1080/02619768.2020.1809650

Kumar, D., \& Gautam, P. (2021). Transition to online higher education during COVID-19 pandemic: turmoil and way forward to the developing country of South Asia-Nepal. Journal of Research in Innovative Teaching \& Learning, 14(1), 93-111. https://doi.org/10.1108/JRIT-10-2020-0051

Li, C., \& Lalani, F. (2020, April 29). The COVID-19 pandemic has changed education forever. This is how. World Economic Forum. https://www.weforum.org/agenda/2020/04/coronavirus-education-global-covid19-onlinedigital-learning/

Loose C., \& Ryan M. (2020), Cultivating Teachers When the School Doors Are Shut: Two Teacher-Educators Reflect on Supervision, Instruction, Change and Opportunity During the Covid-19 Pandemic, Frontiers in Education. 11 https://doi.org/10.3389/feduc.2020.582561

Maican, M., \& Cocorada, E. (2021). Online e Foreign Language Learning in Higher Education and Its Correlates during the COVID-19 Pandemic. Sustainability 2020, 13(781). https://doi.org/10.3390/su13020781

Mahn, H. (2013), Vygotsky and Second Language Acquisition. The Encyclopedia of Applied Linguistics, $\underline{\text { 10.1002/9781405198431.wbeal1272 }}$

Miliszewska, I. (2007). s It Fully ‘On' or Partly 'Off’? The Case of Fully- Online Provision of Transnational Education. Journal of Information Technology Education, 6. https://doi.org/10.28945/229

Montiel-Chamorro, M. (2018). Comparing Online English Language Learning and Face-to-Face English Language Learning at El Bosque University in Colombia. VCU Scholars Compass. https://scholarscompass.vcu.edu/etd/5343 
Ndhlovu, A. (2017). Is it a Practical Strategy of Foreign Language Teaching? Unpacking the Integrated Language and Culture Instruction (ILCI) Method in its Application to Learning of German as a Foreign Language in Zimbabwe. International Journal of Social Sciences \& Educational Studies, 4(3). http://dx.doi.org/10.23918/ijsses.v4i3p22

Oyedotun, T. (2020). A sudden change of pedagogy in education driven by COVID-19: Perspectives and evaluation from a developing country. Elsevier. https://doi.org/10.1016/j.resglo.2020.100029

Parker, C. (2020, June 2). How Are the Pandemic Affecting English Learners? Education Development Center. https://www.edc.org/how-pandemic-affecting-english-learners

Pimentel-Tibon, J. (2020, October 20). The New Normal in Basic Education. Lexology. https://www.lexology.com/library/detail.aspx?g=f4c146a9-7ef0-4bc1-8d6d-e6516a4a14ff

Ribeiro, R. (2020). Teacher experiences: teaching adults English during the Covid-19 pandemic. Cambridge University Press. https://www.cambridge.org/elt/blog/2020/07/02/teacherexperiences-teaching-adults-english-covid-19/\#globalnav

Richards, J. (2006). Communicative Language Teaching Today (First ed.). Cambridge University Press.

Sadiku, L. (2015). The Importance of Four Skills Reading, Speaking, Writing, Listening in a Lesson HouR. European Journal of Language and Literature Studies, 1(1). https://doi.org/10.26417/ej1s.v1i1.p29-31

Shahzad, S., Hussain, J., Sarwat, S., Ghani, U., \& Salem, R. (2020). Impact of Virtual Teaching on ESL Learners' Attitudes under Covid-19 Circumstances at Post Graduate Level in Pakistan. English Language Teaching, 13(9). https://doi.org/10.5539/elt.v13n9p1

Sun, S. (2011). Online Language Teaching: the Pedagogical Challenges. Knowledge Management \& E-Learning: An International Journal, 3(3), 428-447. https://doi.org/10.34105/j.kmel.2011.03.030

Tomacruz, S. (2020, March 9). Duterte suspends classes in Metro Manila March 10-14 over coronavirus threat. Rappler Philippines. https://www.rappler.com/nation/walang-pasokduterte-declares-class-suspensions-metro-manila-coronavirus-threat-march-10-14-2020

UNESCO. (2021, March 31). Education: From disruption to recovery. https://en.unesco.org/covid19/educationresponse 
United Nations. (2020). Policy Brief: Education during COVID-19 and beyond. United Nations. https://www.un.org/development/desa/dspd/wpcontent/uploads/sites/22/2020/08/sg_policy_brief_covid19 and_education_august_2020.pdf

Uro, G., Lai, D., \& Alsace, T. (2020). Supporting English Learners in the COVID-19 Crisis. Council of the Great City Schools. Retrieve from https://eric.ed.gov/?id=ED607280

Verga, L., \& Kotz, S. (2013). How relevant is social interaction in second language learning? Frontiers in Human Neuroscience. https://doi.org/10.3389/fnhum.2013.00550

Waicekawsky, L., Laurenti, L., \& Yuvero, F. (2020). Teaching ESP online during the COVID-19 pandemic: An account of Argentinian students on this teaching modality. LLT Forum 2020, 88(02002). https://doi.org/10.1051/shsconf/20208802002

Watkins, P. (2021). How Did Remote Teaching During the Covid-19 Crisis Affect Faculty's Attitudes and Beliefs About Online Teaching? Proquest.

Yi, Y., \& Jang, J. (2020). Envisioning possibilities amid the COVID-19 pandemic: Implications from English language teaching in South Korea. TESOL Journal. https://doi.org/10.1002/tesj.543

Yousaf M., Uman H., Habib S., (2017). Communicative Language Teaching (CLT), Role of Grammar and Teachers’ Beliefs. Journal of Research in Social Sciences -JRSS, 5(1), 116-123. Retrieved from https://www.proquest.com/scholarly-journals/communicativelanguage-teaching-clt-role-grammar/docview/1869044557/se-2 